\title{
Paslanmaya Maruz Kalmış Tam Ölçekli Betonarme Kolonların Monotonik Yükleme Etkisi Altında Yapısal Davranışlarının İncelenmesi: Korozyon Çalışmaları İçin Öneriler
}

\author{
Hakan YALCINER* (D), Atila KUMBASAROGLU, Mehmet Frrat MERMIT, \\ Rameen KOHISTANI, Aqludin KARIMI
}

Erzincan Binali Yıldırım Üniversitesi Mühendislik Fakültesi, İnşaat Mühendisliği Bölümü, Erzincan, Türkiye

Geliş / Received: 03/11/2018, Kabul / Accepted: 29/03/2019

\begin{abstract}
$\ddot{\mathbf{O z}}$
Korozyona maruz kalmış betonarme yapıların sismik performanslarının tahmin edilmesi korozyona uğramamış yapılara göre daha zordur. Gerçekleştirilen bu deneysel çalışma ile birlikte korozyona maruz kalmış betonarme elemanları üzerine yapılacak olan çalışmalara 1şık tutulması amaçlanmıştır. Beş adet tam ölçekli betonarme kolonu hızlandırılmış korozyon yöntemi kullanılarak farklı korozyon oranları için paslandırılmıştır. Paslandırılmış betonarme kolonları sabit eksenel yük altında monotonik yüklemeye tabi tutularak, akma ve nihai yükleri, süneklik oranları ve enerji yutma kapasiteleri deneysel olarak elde edilmiştir. Betonarme kolonlarındaki gerçek korozyon oranları yükleme deneylerinden sonra betonarme kolonlarının kırılarak ve gömülü olan tüm betonarme donatılarının çıkartılması ile elde edilmiştir. Yapılan deneysel çalışma sonucunda, monotonik yüklemenin tersinir-tekrarlanır yüklemeye göre zayıf yönleri göz önüne alınan deprem indeksleri açısından değerlendirilmiştir. Elde edilen deneysel sonuçlar doğrultusunda ileriki korozyon çalışmaları için önemli önerilerde bulunulmuştur. Gerçekleştirilen bu çalışma kapsamında, paslanmış betonarme kolonlarının monotonik yükleme etkisi altında süneklik oranları ve enerji yutma kapasiteleri artan korozyon oranına bağlı olarak azalmıştır. Monotonik yükleme etkisi altında pasın belirli oranlarına kadar sağlamış olduğu sargı etkisi ve buna bağlı olarak deprem indekslerindeki artışlar net bir şekilde görülememiştir. Tek doğrultuda göçme modu kabulü ile yapılacak olan sismik değerlendirmelerde kullanılmak üzere paslanmış betonarme kolonların süneklik ve enerji yutma kapasitelerinin tahmin edilebilmesi için iki ampirik model geliştirilmiştir.
\end{abstract}

Anahtar Kelimeler: Korozyon, Betonarme donatısı, Kolon, Monotonik yükleme.

\section{Investigation of Structural Behavior of Full-Scale Reinforced Concrete Columns Subjected to Corrosion under Monotonic Loading Effect: Suggestions for Corrosion Studies}

\begin{abstract}
The estimation of the seismic performance of reinforced concrete structures exposed to corrosion is more difficult than uncorroded structures. By this experimental study, it was aimed to keep light on the studies to be done on the reinforced concrete members exposed to corrosion. Five full-scale reinforced concrete columns were corroded for different corrosion levels by using the accelerated corrosion method. The corroded reinforced concrete columns were subjected to monotonic loading under constant axial load and, their yield and ultimate loads, ductility ratios and energy absorption capacities were obtained by experimentally. The actual corrosion levels in the reinforced concrete columns were obtained by breaking the reinforced concrete columns after the loading tests and extracting all embedded reinforced concrete bars from the concrete. As a result of this experimental study, the weaknesses of monotonic loading compared to reversed-cyclic loading were evaluated for considered earthquake indicators. Based on the obtained experimental test results, important recommendations were suggested for further corrosion studies. Within the scope of this study, the ductility ratios and energy dissipation capacities of corroded reinforced concrete columns were decreased as the corrosion levels were increased under the influence of monotonic loading. The confinement effect up to a certain value of corrosion levels and regarding with increasing in earthquake indicator could not been clearly observed under the influence of monotonic loading. Two empirical models to predict the ductility ratios and energy dissipation capacities were developed to be used for seismic assessment of corroded reinforced concrete columns considering the unilateral failure mode.
\end{abstract}

Keywords: Corrosion, Reinforcement bar, Column, Monotonic loading. 


\section{Giriș}

Betonarme donatısinda meydana gelen paslanma yapının yalnızca servis ömrünü değil, aynı zamanda taşıma gücü sınır durumunu da olumsuz yönde etkilemektedir. Betonarme elemanlarında korozyon sürecinin başlaması ile birlikte, donatı yüzeyini çevreleyen koruyucu film tabakası zamanla zarar görmekte ve korozyonun kimyasalmekanik etki döngüsü başlamaktadır. Koruyucu film tabakasının zarar görmesinden sonra ilk aşamada meydana gelen kimyasal reaksiyon sonucunda donat1 yüzeyini kaplayan ve farklı türlerde oluşan korozyon ürünü betonarme donatısını çevrelemektedir. $\mathrm{Bu}$ süreç betonun geçirgenliğine bağl1 bir hızda gerçekleşirken, devam etmekte olan bu kimyasal süreç korozyonun donatı ve beton üzerine mekanik etkileri ile hedeflenen yapı performansının servis yükleri etkisi altında dahi olumsuz yönde etkilenmesine neden olabilmektedir. Donatı yüzeyini çevreleyen korozyon ürünü zamana bağlı olarak betonarme donatısı çapının azalmasına neden olurken, donatı yüzeyini çevreleyen korozyon ürünü aynı zamanda betonun gözenek oranına bağlı olarak donatıdan beton yüzeyine uygulanan radyal basınç etkisi ile birlikte beton üzerinde de etkisini göstermeye başlar. Bu etkinin beton basınç dayanımına, pas payıdonatı çapı ve korozyon oranlarına bağlı olarak nasıl değiştiği Yalciner vd. (2012) tarafından yapılan deneysel çalışma ile birlikte net bir şekilde ortaya konulmuştur. Her ne kadar korozyon belirli bir seviyeye kadar beton ve donatı arasındaki kayma gerilmeleri ile ifade edilen aderans kuvvetini, yukarıda belirtilen diğer parametrelere bağ 1 olarak artırsa da, artan korozyon oranı ile birlikte aderans kuvvetindeki azalım ve buna bağlı donatı sıyrılmasındaki artış sismik davranış ile ortaya çıkmaktadır. Taşıma gücü varsayımları doğrultusunda beton ile donatı arasında tam bir aderansın olduğu kabulü, artan korozyon oranına bağlı olarak göreli kat ötelemelerini artırmakta ve özellikle tasarım aşamasında göz önüne alınan ve performansa dayalı tasarım kapsamında hedeflenen deplasman değerlerinden olası sismik yer hareketleri sonucunda uzaklaşılmaktadır. Betonarme donatisinda meydana gelen korozyonun mevcut yapılar üzerinde olas1 depremlerde yarattığ 1 sismik risk nedeni ve korozyona maruz kalmış betonarme elemanlarının taşıma gücü kapasitelerinin belirlenebilmesi için birçok araştırmacı tarafından farklı analitik ve deneysel çalışmalar yürütülmüş olup hala yürütülmeye devam edilmektedir.

Sonlu elemanlar yöntemi kullanılarak korozyonun betonarme elemanlarının mekanik özellikleri üzerine etkileri (Liu and Weyers, 1998; Coronelli and Gambarova, 2004; Hanjari et al., 2011) ile özellikle korozyon çalışmalarının oldukça zahmetli ve ağır iş gücü gerektirmesinden dolayı ilk aşamada paslanmış betonarme kirişlerinin taşıma gücü kapasitelerinin ( Lee et al., 1999; Coronelli and Gambarova, 2004; Jnaid and Aboutaha, 2016) tahmin edilmesi üzerine mevcut literatürde çalışmalar kapsamlı bir şekilde yürütülmüştür. Campione et al. (2017) tarafından gerçekleştirilen bir çalışmada, sonlu elemanlar yönteminin korozyonun karmaşı yapısı ile birlikte kullanılması, hasar almış malzemenin birçok tutucu kuralı ihtiva etmesi gerekliliği belirtilmiştir. Özel çalışma alanları gerektiren bu durum, ülkemizde kullanılan yazılımlarda dahi korozyonun etkisi yalnızca donatı çapındaki azalma olarak göz önüne alınmakta ve korozyonun diğer birçok etkisi ihmal edilmektedir. Bundan dolayı, betonarme elemanlarının taşıma gücü kapasitelerinin daha pratik ve basit yöntemler ile tahmin edilebilmesi için gerçekleştirilen deneysel çalışmalar ve geliştirilen ampirik modeller son yıllarda hızla artmaktadır.

Servis yüklerinin kullanıldığı ve servis yükleri bulunmadan paslandırılmış betonarme kirişleri üzerine yapılan en bilindik deneysel çalışmalardan biri El Maaddawy et al. (2005) tarafından gerçekleştirilen çalışmadır. Yapılan çalışma servis yükleri kullanılarak 
paslandırma aşamasında birincil korozyon çatlak genişlikleri etkisinin taşıma gücüne olan etkisini incelemek için önemli bir yere sahiptir. Gerçekleştirilen çalışmada sekiz adet betonarme kirişi hızlandırılmış korozyon yöntemi kullanılarak paslandırılmış ve eğilme deneyleri gerçekleştirilmiştir. El Maaddawy et al. (2005) tarafindan yapılan deneysel çalışmada elde edilen korozyon oranları betonarme kirişlerinden çıkartılan kupon donatıları üzerinden sağlanmıştır. Paslandırılmış betonarme kirişleri üzerine gerçekleştirilen diğer bir deneysel çalışma ise O'Flaherty et al. (2008) tarafindan yapılan çalışmadır. Paslandırılmış betonarme kirişlerinin artık moment kapasitelerinin tahmin edilebilmesi için gerçekleştirilen çalışmada, hızlandırılmış korozyon yöntemi ile paslandırılan betonarme kirişlerindeki pas oranları Faraday Kanununa göre elde edilmiştir. Diğer bir ifadeyle, elde edilen korozyon oranları gerçek korozyon oranları olmayıp teorik olarak elde edilen korozyon oranlarıdır. Betonun göstermiş olduğu direnç nedeni ile paslandırma çalışmaları için elde edilen gerçek korozyon oranları her zaman Faraday Kanununa göre hesaplanan teorik korozyon oranlarından daha azdır. Bu durum mevcut literatürdeki birçok çalışma ile ifade edilmiştir (Auyeung et al., 2000; Yalciner vd., 2012; El Maaddawy et al., 2006; Paul et al., 2016; Chung et al., 2004; Amleh and Ghosh, 2006). 2018 yılında tam ölçekli betonarme kirişlerinin taşıma gücü kapasitelerinin tahmin edilebilmesi için gerçekleştirilen diğer bir deneysel çalışma Bicer vd. (2018) tarafından yapılmıştır. Çalışmada servis yükleri olmadan ve hızlandırılmış korozyon yöntemi kullanılarak yaşlandırılan her bir betonarme kirişindeki tüm donatılar için gerçek korozyon oranları ve dağılımları elde edilmiştir. Yapılan çalışmada mevcut literatürde yer alan modeller (El Maaddawy et al., 2005; Azad et al., 2010; Ahmad, 2017); paslanmış betonarme kirişlerinin taşıma gücü kapasitelerinin tahmin edilebilmesi için etriye donatısında meydana gelen korozyon oranını da göz önüne alarak geliştirilmiştir. Geliştirilen ampirik model her ne kadar korozyon akım yoğunluğuna bağlı bir model olsa da, sargı donatılarının özellikle korozyon etkisi altında taşıma gücü kapasitesine olan etkisini vurgulamak için oldukça önemlidir. Aynı şekilde her ne kadar Bicer vd. (2018) tarafından gerçekleştirilen çalışmada betonarme kirişleri servis yükleri etkisi altında paslandırılmamış olsa da, servis yükleri kullanılarak veya kullanılmadan paslandırılan ve çatlak genişlikleri üzerine yapılan çalışmalardaki çelişkiler Malumbela et al. (2009) tarafından çok iyi bir şekilde ortaya konulmuştur ve yapılan kritik değerlendirmede, birçok çalışmada birincil korozyon çatlak genişlikleri için çelişkilerin yükleme türüne bağlı olarak halen devam ettiği belirtilmiştir. Servis yükleri etkisi altında veya servis yükleri olmadan paslandırılan betonarme elemanları için, yükleme türünün korozyon oranına bağlı olarak donatı çapındaki azalmayı etkilemeyeceği göz önüne alındığında, servis yükleri olmadan paslandırılan betonarme elemanlarından elde edilen deneysel verilerin, servis yükleri kullanılarak elde edilen deneysel veriler ile donatı çapına bağlı olarak ilişkilendirilebileceği önerilebilir.

Mevcut literatürde paslanmış betonarme kirişleri üzerine yapılan çalışmaların ardından, korozyona maruz kalmış betonarme kolonların sismik davranışlarının incelenmesi ve güçlendirme yöntemlerine (Kalyoncuoğlu vd., 2013) yönelik çalışmalar oldukça yeni olup son yıllarda bu konu üzerine yapılan çalışmaların sayısı hızla artmaktadır. Korozyona maruz kalmış betonarme kolonları üzerine gerçekleştirilen en bilindik çalışmalardan biri Ma et al. (2012) tarafından gerçekleştirilmiştir. Yapılan çalışmada on adet daire kesitli paslandırılmış betonarme kolonlarının deneyleri tersinir yükleme etkisi altında gerçekleştirilmiştir. Eksenel yük oranı 0.15 ile 0.90 arasında değişkenlik göstermiştir. Uygulanan eksenel yük oranları 
korozyon oranın artması ile birlikte artırılmıştır. Ortalama gerçek korozyon oranları yükleme deneylerinden sonra elde edilmiş ve yapılan çalışmada korozyon oranları \%0 ile \%15.1 arasında değişkenlik göstermiştir. Ma et al. (2012) tarafından yapılan çalışmada, paslanmış betonarme kolonlarının akma ve nihai yük dayanımları ve süneklik oranlarının tahmin edilebilmesi için üç adet ampirik model geliştirilmiştir. Paslanmış betonarme kolonları üzerine gerçekleştirilen diğer bir deneysel çalışma ise Meda et al. (2014) tarafindan yapılmıştır. Kare kesitli paslandırılmış betonarme kolon deneyleri tersinir-tekrarlanır yükleme etkisi altında ve 0.22 oranında tek bir eksenel yük için yapılmıştır. Meda et al. (2014) tarafından yapılan deneysel çalışmada etriyeler paslandırılmamış olup, boyuna betonarme donatıları ise kolon boyunun üçte bir oranında paslandırılmıştır. Böylelikle, sargılama etkisinin aderans dayanımına ve buna bağlı olarak aderans dayanımındaki kaybın toplam yanal yer değiştirmeye katkısı etriyelerin korunması ile birlikte ihmal edilmiştir. Yapılan çalışmada kolon boyuna donatılarındaki korozyon oranı \%20 olup; elde edilen korozyon oranı Faraday Kanununa göre hesaplanan teorik korozyon oranıdır. Paslanmış betonarme kolonları üzerine gerçekleştirilen diğer bir çalışma ise Guo et al. (2015) tarafindan yapilan deneysel çalışmadır. Tersinir artımlı yük etkisi altında üç adet betonarme kolonu için yükleme deneyleri gerçekleştirilmiştir. Yapılan çalışmada betonarme kolonları tek bir eksenel yük oranı için deneye tabi tutulmuş olup eksenel yük oranı 0.10 'dur. Çalışmada korozyon oranları sirasiyla $\% 5, \% 10$ ve $\% 15$ olarak tasarlanmıştır. Ma et al. (2012) ve Meda et al. (2014) tarafindan yapilan çalışmalarından farklı olarak, Guo et al. (2015) boyuna ve sargı donatılarındaki gerçek korozyon oranlarını hesaplamıştır. Boyuna donatılardaki ortalama gerçek korozyon oranlar1 \%5.07 ve \%15.24 arasında değişkenlik gösterirken, etriyelerdeki gerçek ortalama korozyon oranları \%11.20 ile \%30.19 arasında değişkenlik göstermiştir. 2016 yılında Yang et al. (2016) tarafindan korozyon oranlar $\% 5, \% 10, \% 15$ ve $\% 20$ olan $210 \times 210 \mathrm{~mm}$ kare kesitli ve $1500 \mathrm{~mm}$ kolon boyuna sahip betonarme kolonları tersinir artımlı yük etkisi altında deneye tabi tutulmuştur. Yapılan çalışmada betonarme kolonlarının 28 günlük beton basınç dayanımları 46.4 MPa olarak verilmiştir. Betonarme kolonları tek bir eksenel yük oranı için deneye tabi tutulmuş olup eksenel yük oran1 0.18 'dir. Gerçekleştirilen deneysel çalışmada paslanmış betonarme kolonların sünekliğini ve enerji yutma kapasitelerini tahmin etmeye yönelik iki adet ampirik model geliştirilmiştir. Yang et al. (2016) tarafından yapılan çalışmada paslanmış betonarme kolonlarının sünekliği korozyon oranına bağlı olarak azalırken, bu durum korozyonun sağlamış olduğu sargı etkisi ile birlikte diğer çalışmalarda farklılık göstermiş ve belirli korozyon oranlarına kadar paslanmış betonarme kolonlarının sünekliğinin arttığ1 gözlenmiştir (Ma et al., 2012; Guo et al., 2015; Li et al., 2018). Mevcut literatürde korozyona maruz kalmış betonarme kolonlarının yapısal davranışlarının incelenmesi için gerçekleştirilen diğer bir çalışma Li et al. (2018) tarafından yapılmıştır. 2018 y1lında Li et al. (2018) tarafindan yapılan deneysel çalışmada aynı kolon için eşit oranlarda paslandırılmamış boyuna donatıların etkisi paslandırılmış betonarme kolonların sismik davranışları için incelenmiştir. Tersinir artımlı yük etkisi altında dört adet dikdörtgen kesitli betonarme kolonu için yükleme deneyleri yapılmıştır. Yapılan çalışmada betonarme kolonların 28 günlük küp beton basınç dayanımları 50.2 MPa olarak verilmiştir. Betonarme kolonları iki farklı eksenel yük oranları için deneye tabi tutulmuş olup eksenel yük oranları 0.10 ve 0.30 olarak göz önüne alınmıştır. Li et al. (2018) tarafından yapılan deneysel çalışmada paslanmış betonarme kolonların yapısal davranışlarını tahmin etmeye yönelik bir 
model geliştirilmemiştir. Gerçekleştirilen deneysel çalışmada deneye tabi tutulan her bir betonarme kolonunun süneklik oranları korozyon oranının artması ile birlikte artmıştır. Bunun nedeni, süneklik oranlarının deplasman bazlı bir yöntem ile hesaplanmasıdır. Korozyondan dolayı betonarme donatısının ve kesitin daha erken akması, deplasmana dayalı sünekliliğin tersinir-tekrarlanır yükler altında paslanmış betonarme kolonları için yanlış bir sonuca neden olmaktadir.

Yukarıda özet olarak sunulan ve paslanmış betonarme kolonları üzerine gerçekleştirilen deneysel çalışmaların bağımlı değişkenlerinin sinırlı olması (tek bir beton sinıfi veya eksenel yükün kullanılması) sebebi ile deney verileri arasında paslanmaya maruz kalmış betonarme kolonlarının, deplasman süneklik oranları ve enerji yutma kapasiteleri açısından çelişkiler bulunmaktadır. $\mathrm{Bu}$ makalenin yazarları tarafindan yürütülmekte olan TÜBİTAK 3501 projesi kapsamında bu çelişkilerin giderilmesi hedeflenmiş olup, devam eden çalışmada otuz adet tam ölçekli betonarme kolonu üç farklı beton basınç dayanımı (C8, C20 ve C30) ve iki eksenel yük (0.20 ve 0.40$)$ etkisi altında dört farklı korozyon oranı için çalışmalar yürütülmektedir. Söz konusu otuz adet betonarme kolonları için yükleme programı tersinir-tekrarlanır, artımlı ve yer değiştirme kontrollü olarak FEMA 461 (2007) protokolüne göre gerçekleştirilmektedir. FEMA 461 (2007) protokolü tersinirtekrarlanır yükleme programının ve hasar seviyelerinin başlangıç noktasının tahmin edilmesinin monotonik yükleme sonuçlarına göre değerlendirilmesini önemle önermektedir. Yapılan çalışmada da FEMA 461 (2007) göz önüne alınarak ve bu çalışmaya konu olan beş adet betonarme kolonu için monotonik yükleme deneyleri gerçekleştirilerek yükleme programı oluşturulmuştur. Korozyona maruz bırakılmış tam ölçekli beş adet betonarme kolonu üzerinde gerçekleştirilen çalışmadan elde edilen deney sonuçlarının değerlendirilmesinin ve yukarıda sözü edilen çalışmalardaki çelişkilerin ortaya konularak ileriki çalışmalara 1 şı tutması amacı ile oldukça önemli olduğu düşünülmektedir.

\section{Materyal ve Metot}

\subsection{Malzeme ve kesit özellikleri}

Mevcut çalışma kapsamında betonarme kolon numunelerinde kullanılan özdeş altı adet betonarme donatısı için çekme deneyleri ASTM A370 (2008) standartlarına göre gerçekleştirilmiş olup, betonarme boyuna donatıları için: akma dayanımı $500 \mathrm{MPa}$, kopma dayanımı $590 \mathrm{MPa}$, akma ve kopmadaki birim şekil değiştirme değerleri sirasiyla 0.0022 ve 0.1156 olarak hesaplanmıştır. Beton döküm işleri aynı gün ve aynı beton basınç dayanıma sahip C30 betondan üretilmiştir. Betonarme kolon deneylerinin birbirlerine yakı zaman dilimlerinde deneye tabi tutulamama ihtimali göz önüne alınarak ve zamana bağlı beton basınç dayanımlarındaki artışların mümkün olduğunca azaltılması için betonarme kolonları paslandırma sürecinden önce ve beton dökümünden üç ay sonra paslandırma havuzuna alınmıştır. Betonarme kolonları ile aynı şartlarda küre bırakılan ve yükleme deney günü elde edilen silindir beton numunelerinin ortalama basınç dayanımları 37.46 MPa olarak hesaplanmıştır.

Çalışma kapsamında deneyleri yapılan betonarme kolonlarının kesit özellikleri Şekil 1 'de verilmiştir. Malzeme ve kesit özellikleri özdeş olan betonarme kolonları beş farklı korozyon oranı için paslandırılarak $\left(\mathrm{C} 30_{1}=\right.$ $\% 0.00, \mathrm{C} 30_{2}=\% 1.46, \mathrm{C} 30_{3}=\% 2.38, \mathrm{C} 30_{4}=$ $\left.\% 4.16, \quad \mathrm{C} 30_{5}=\% 6.36\right)$ eksenel yükleme deneyleri gerçekleştirilmiştir. Şekil 1'de gösterilen betonarme kolonlarının net boyu $2190 \mathrm{~mm}$, kolon yükseklik ve genişlikleri 300x300 mm olarak tasarlanmıştır. Her bir betonarme kolonu için 8 adet $16 \mathrm{~mm}$ çapında nervürlü boyuna donatılar kullanılmıştır. 8 
mm çapındaki etriyeler mesnet bölgesine doğru sıklaştırılarak donatı düzenleri gerçekleştirilmiştir. Her bir betonarme kolonunda kullanılan pas payı özdeş olup 35 mm'dir.
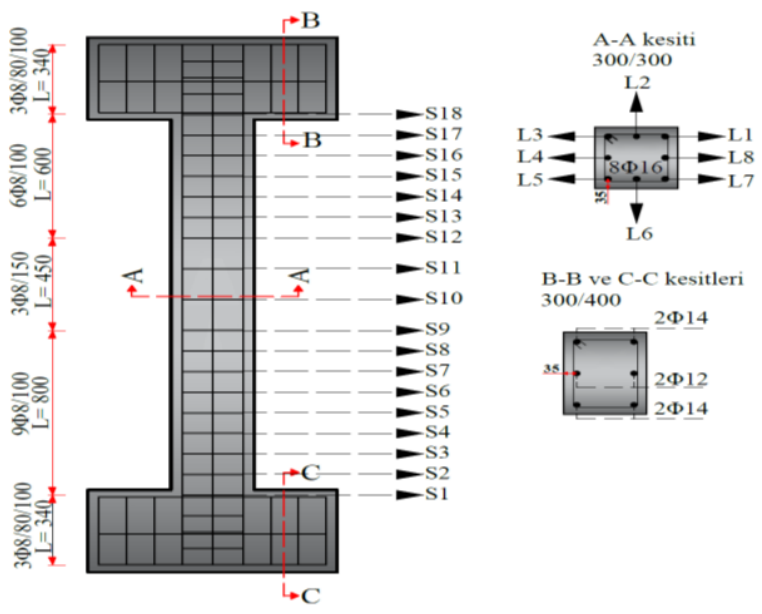

Şekil 1. Kesit özellikleri ve betonarme donatılarının kodlanması

\subsection{Hızlandırılmış korozyon yöntemi}

Çalışma kapsamında kullanılan tam ölçekli paslandırma havuzu Şekil 2'de gösterilmektedir. Şekil 2'de gösterilen tam ölçekli paslandırma havuzunun betonarme olması ve dolayısıyla olası elektrik akım kaçaklarını önlemek amacı ile paslandırma havuzunun tüm alt ve yan yüzeyleri plastik membran ile kaplanmıştır. Donatı bağlama ve beton döküm işlerinden önce her bir betonarme kolonundaki tüm boyuna ve sarg1 donatılarının ilk kütleleri kayıt altına alınmıştır. Donatıların ilk ve paslandırma sonraki son kütlelerinin ölçülebilmesi için iki noktadan yük hücreli özel bir terazi kullanılmıştır. Güç kaynağından gelen pozitif yüklemenin beton içerisindeki donatılara aktarılabilmesi için donatı montaj işlemlerinden sonra ve beton döküm işlemlerinden önce, her bir boyuna donatılarına ve etriyelere $4 \mathrm{~mm}$ çapındaki bakır kablolar bağlanmıştır (bkz Şekil 3). Şekil 2'de her bir betonarme kolonlarına bağlanan ayarlanabilir 60 Volt kapasitesine sahip güç kaynakları betonarme donatılarından uzatılan bakır kablolara pozitif yükleme olarak bağlanmıştır. Güç kaynağındaki devreyi tamamlayacak eksi terminal yüklemesi ise betonarme havuzunu ve her bir betonarme kolonu çevreleyen bakır levhalar yardımı ile sağlanmıştır. Kontrollü paslanmanın sağlanabilmesi için sistemden geçen akım her 60 saniyede bir bilgisayara kayıt aktaran voltmetreler yardımı ile kayıt edilmiştir. Sistemden geçen akımın bilinmesi ile birlikte kontrollü paslandırma (teorik paslandırma) Faraday Kanunu'na göre Denklem 1 yardımı ile hesaplanmıştır.

$m=\frac{t(s) \times I(A) \times 55.847}{2 \times 96,487}$

Denklem 1'de $t$ uygulanan korozyon süresini, $I$ ise sistemden geçen akımı göstermektedir. Mevcut çalışma için teorik olarak elde edilen korozyon oranları sirasiyla \%6.50, 8.01, 12.00, 17.00'dir. Paslandırma sürecinin hızlandırılması amacı ile paslandırma havuzuna su kütlesinin $\% 5$ 'i oranında sodyum klorür (NaCI) ilave edilmiştir. Çalışma kapsamında su konsantrasyonu ve sicaklık verileri üzerine bir değerlendirme yapılmamıştır.

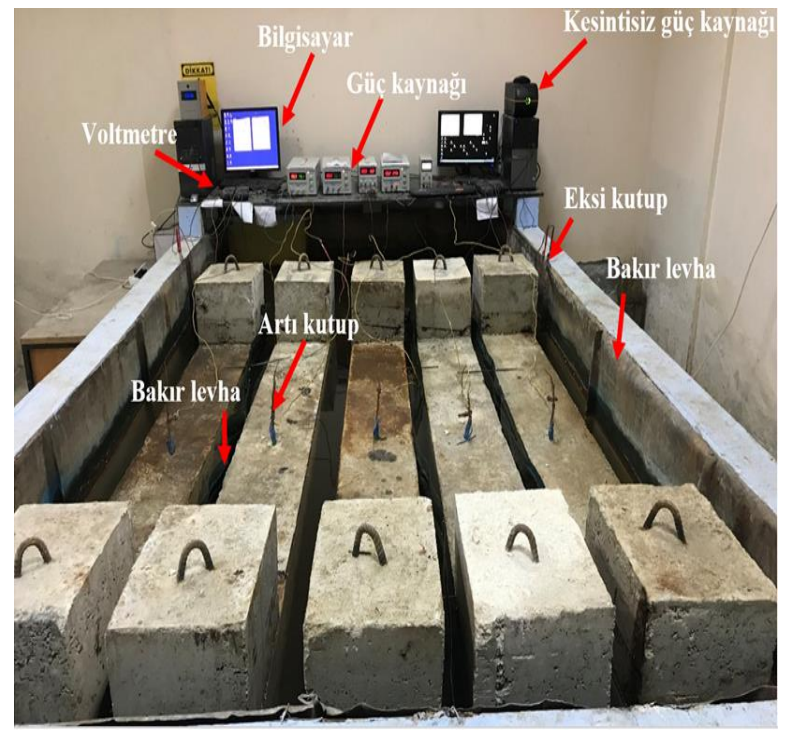

Şekil 2. Paslandırma havuzu ve düzenek. 


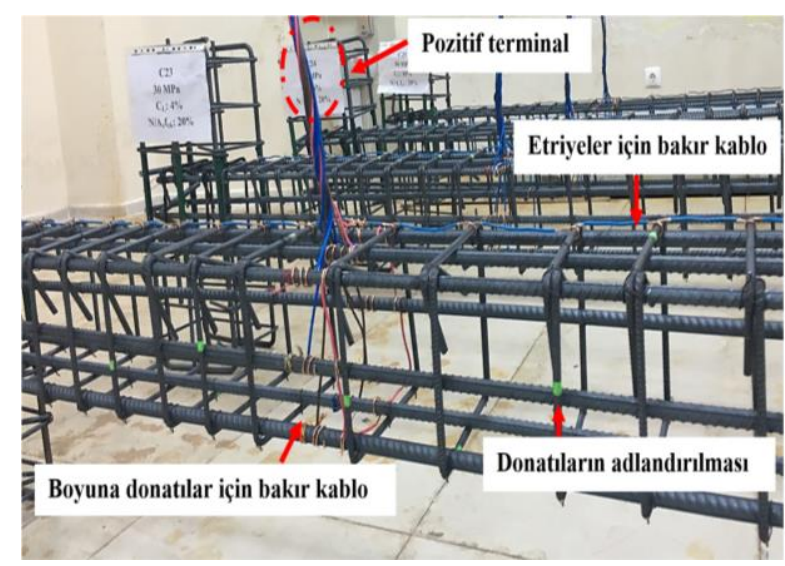

Şekil 3. Bakır kabloların boyuna ve sarg1 donatılarına bağlanması.

\subsection{Yükleme ve ölçüm düzeneği}

Şekil 4'de mevcut çalışma için kullanılan yükleme düzeneği gösterilmektedir. Şekil 4ab'de gösterildiği üzere, çeşitli idealleştirme ve basitleştirme işlemleri yapılarak, yapısal bir çerçeveden alınan deneysel numuneler eksenel yük ve yanal yüke maruz olacak şekilde deneylere tabi tutulmuştur. Böylece, eğilme davranışına sahip olan deneysel kolonlarda çatlamanın, kesitin akma dayanımına ulaşmadan önce gerçekleşeceği tasarım şartı olarak kabul edilmektedir. Deneylerden elde edilen veriler yapisal davranışın temel fikirleri için oldukça önemlidir. Deneysel çalışmada yüklerin ve buna bağlı olarak numune sınır koşullarının (örneğin; kolon kesit özellikleri, kolonların mesnetlenme türü, kolonun eksenel ve yanal yüklenme bölgeleri) mümkün olduğunca gerçeğe yakın olarak benzeştirilebilmesi için eksenel yük yanal yükün bir fonksiyonu olacak şekilde yer değiştirme kontrollü hidrolik silindirler kullanılmıştır. \%20 sabit eksenel yük (65 ton) için iki adet 100 ton kapasiteli hidrolik silindirler kullanılırken, yanal yüklemede ise artımlı olacak şekilde 60 ton kapasiteli bir adet hidrolik silindir kullanılmıştır. Eksenel yük sağlayan silindirler güçlü zemine monte edilirken, yanal yük sağlayan silindir ise reaksiyon duvarına monte edilmiştir. Deney numunesinin düzlem-dışı hareket etmemesi için gerekli önlemler alınmıştır. Yükleme düzeneğinde eksenel yük için simetriklik sağlanmış ve yüklemenin sadece düşey yönde etkili olması planlanmıştır. Aynı şartlar yanal yükleme için de geçerli olup, eğilmenin sadece yükleme yönünde olması sağlanmıştır. Hidrolik silindirler deneysel çalışmada yer değiştirme kontrollü olarak kullanılmıştır. Yanal yükleme, numune göçünceye kadar monotonik olarak artırılmıştır. Eksenel yükler ise planlanan seviyede deney sonuna kadar sabit bırakılmıştır.

Her bir betonarme kolonunun deneyinde eksenel yükleme için iki adet manometre ve yanal yükleme için de bir adet 60 ton kapasiteli yük hücresi kullanılmıştır. Betonarme kolonlarının yanal deplasmanlarını ölçmek için yanal yükün uygulandığı kiriş seviyesinde bir adet $200 \mathrm{~mm}$ kapasiteli potansiyometre ayrı olarak tasarlanan güçlü bir aparata monte edilmiştir. Birçok deneysel çalışmalarda ölçüm sistemleri için gerekli aparatlar beton içerisine açılan delikler yardımı ile sağlanmaktadır. Beton içerisine yerleştirilen aparatların eğilmesi veya bu aparatlara yakın noktalarda betonun hazır almasindan dolayı deneysel verilerin etkilenmesinin söz konusu olduğu düşünülmektedir. Mevcut çalışmada bu durum özellikle göz önüne alınmıştır. Şekilde 4'de gösterildiği gibi potansiyometreler doğrudan deney numunesine (beton yüzeyine) monte edilmemiştir. Ölçüm cihazları alüminyum bir kutu profil üzerine vidalanmıştır. Alüminyum kutular ise kolon yüzeyine yapıştırılmış olan $45 \times 45 \mathrm{~mm}$ tahta takozlara ataçlanmıştır. Alüminyum kutular deney sırasında kesit bütünlüğünün korunabilmesi amacıyla karşılıklı olarak yaylı bir sistem ile birbirine iliştirilmiştir. Bu yay sistemi, kesit sistemini bir arada tutacak kadar güçlü ve lokal deformasyonlar altında deforme olabilecek kadar esnektir. 

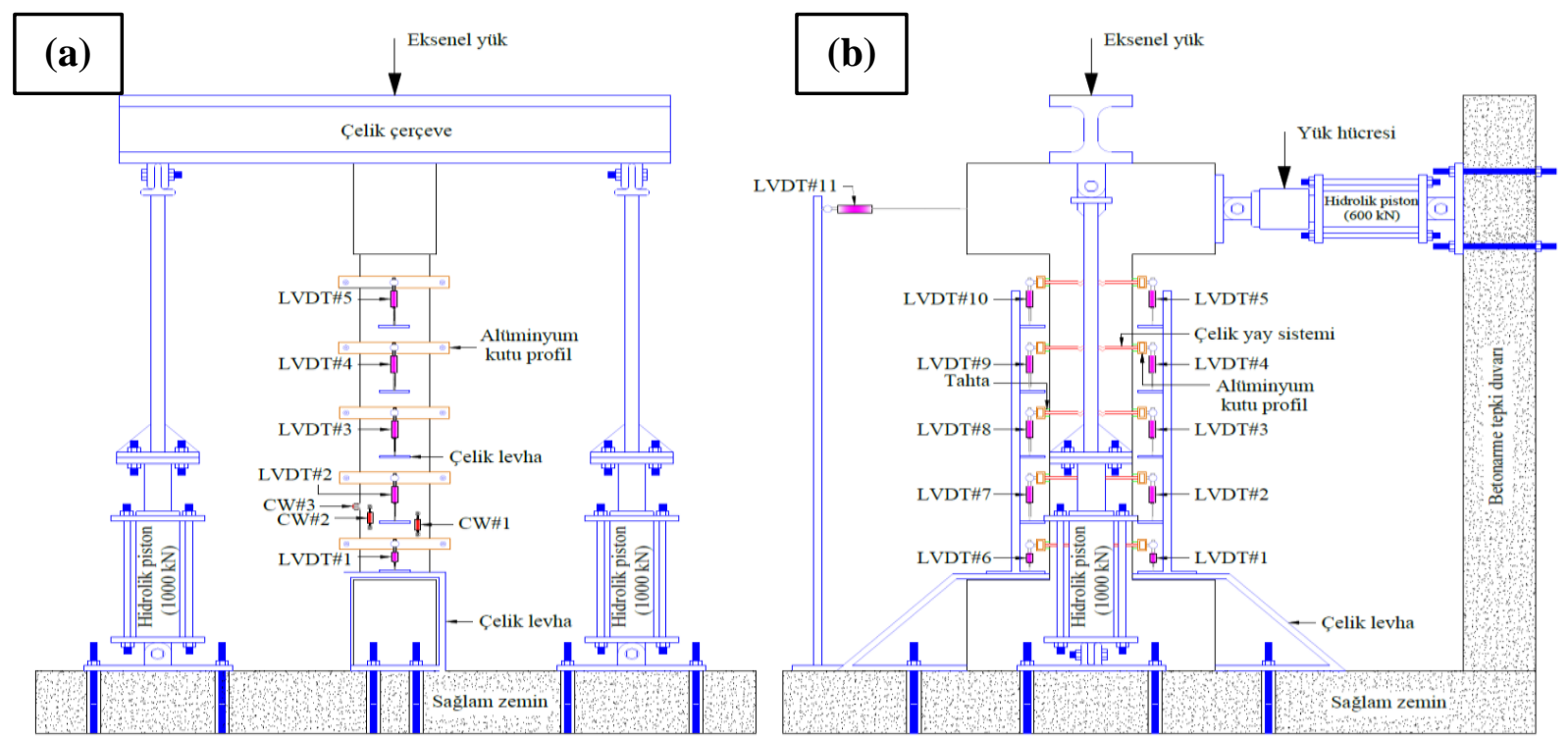

Ön görünüș

Yan görünüş
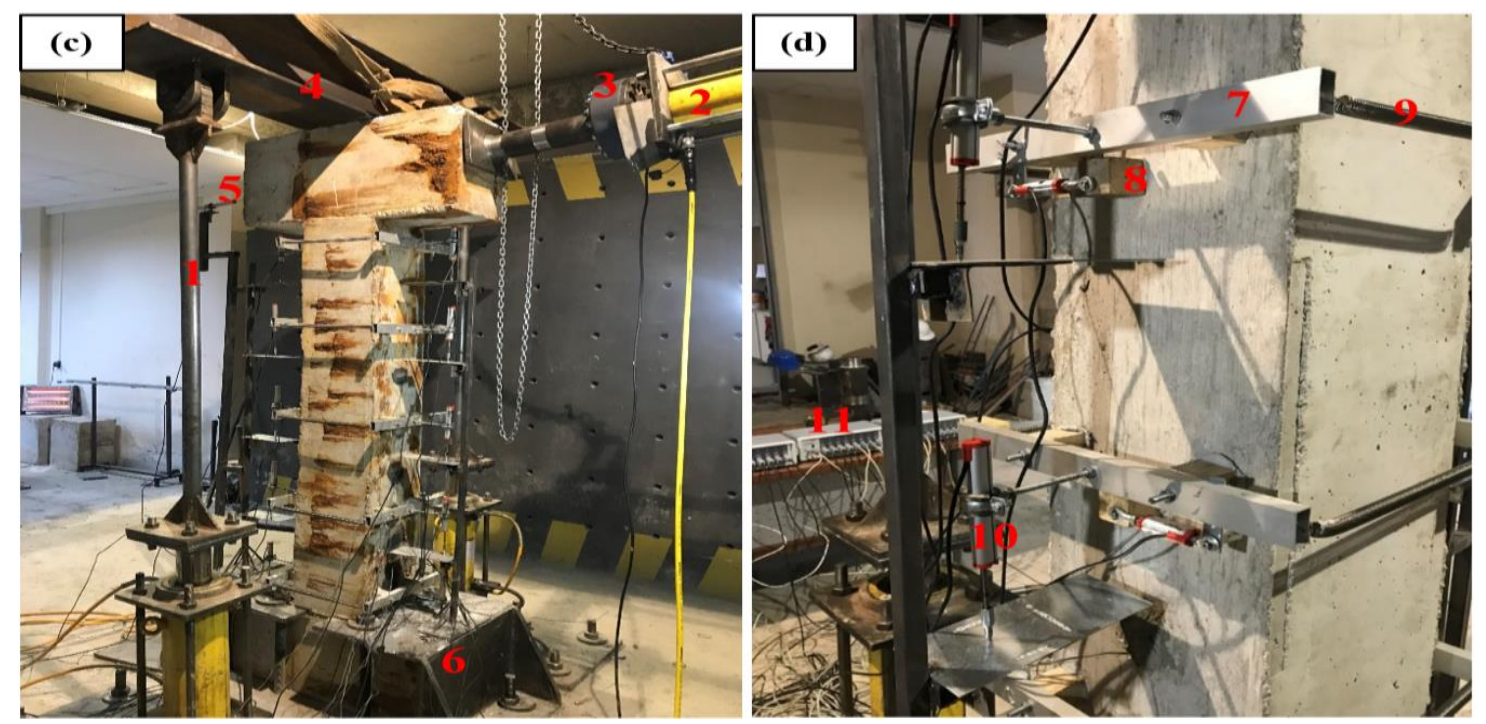

Şekil 4. Deney düzeneği: (a) ön görünüş; (b) yan görünüş; (c) deney düzeneği; (d) ölçüm düzeneği için detay resim. 1: Eksenel yük; 2: Yanal yük; 3: Yük hücresi; 4: Çelik I kirişi; 5: Yanal ötelenme için LVDT; 6: Çelik plaka; 7: Alüminyum kutu; 8: Tahta takoz; 9: Yay sistemi; 10: Kolon boyunca eğrilik için LVDT; 11: Data logger

\section{Bulgular}

\subsection{Elde edilen korozyon oranları ve dağılımları}

Yükleme deneylerinden sonra tüm betonarme kolonları kırilarak betonarme boyuna ve sarg1 donatıları daha önceden belirlenen sıralamaya göre beton içerisinden çıkartılmıştır. Şekil 5'de gösterildiği üzere, betonun kırılması ile çıkartılan betonarme donatıları için hem kimyasal ve hem de mekanik temizleme işlemleri ASTM G1-03 (2003) yönetmeliğine göre yapılmıştır. Şekil 5'de de tüm aşamaları ile birlikte gösterildiği üzere, kimyasal temizleme işlemleri için betonarme donatıları hidroklorik asit banyosunda 30 dakika süre ile bekletilirken, kimyasal temizleme işlemleri sonrasında tel firça yardımı ile tüm boyuna donatılar ve etriyeler üzerinde bulunan korozyon ürünleri donatı yüzeyinden mekanik temizleme yöntemi ile arındırılmıştır. 


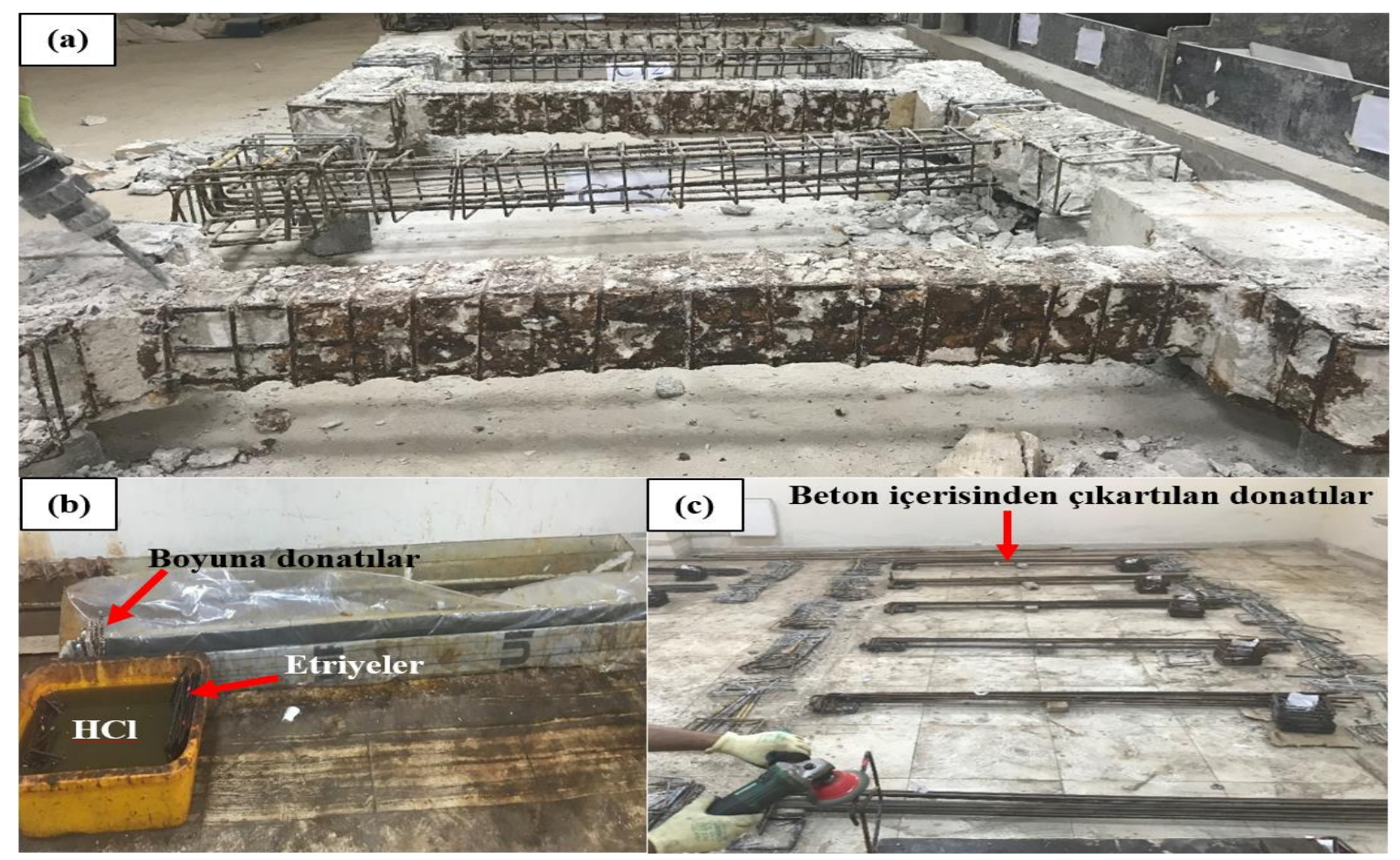

Şekil 5. Gerçek korozyon oranlarının elde edilmesi: (a) betonarme kolonlarının kırılması; (b) kimyasal temizleme işleri; (c) mekanik temizleme işleri.

Kimyasal ve mekanik donatı temizleme işlemlerinden sonra tüm boyuna ve sarg1 donatılarının kütleleri tekrar tartılarak, Denklem 2 yardımı ile her bir betonarme donatısındaki gerçek korozyon oranları elde edilmiştir.

$C_{L}=\frac{W_{i}-W_{f}}{W_{i}} \times 100 \%$

Denklem 2'de $C_{L}$ korozyon oranını, $W_{i}$ betonarme donatılarının paslanmadan önceki kütlesini, $W_{f}$ ise paslanmış ve ardından pas ürünün kaldırılarak tekrar tartım ile elde edilen donatıların son kütlelerini ifade etmektedir. Her bir betonarme kolonu için elde edilen korozyon dağılımları Şekil 6'da gösterilmiş olup ve özetlenen gravimetrik deney sonuçları ise Tablo 1'de verilmiştir. 
Paslanmaya Maruz Kalmış Tam Ölçekli Betonarme Kolonların Monotonik Yükleme Etkisi Altında Yapısal Davranışlarının İncelenmesi: Korozyon Çalışmaları İçin Öneriler
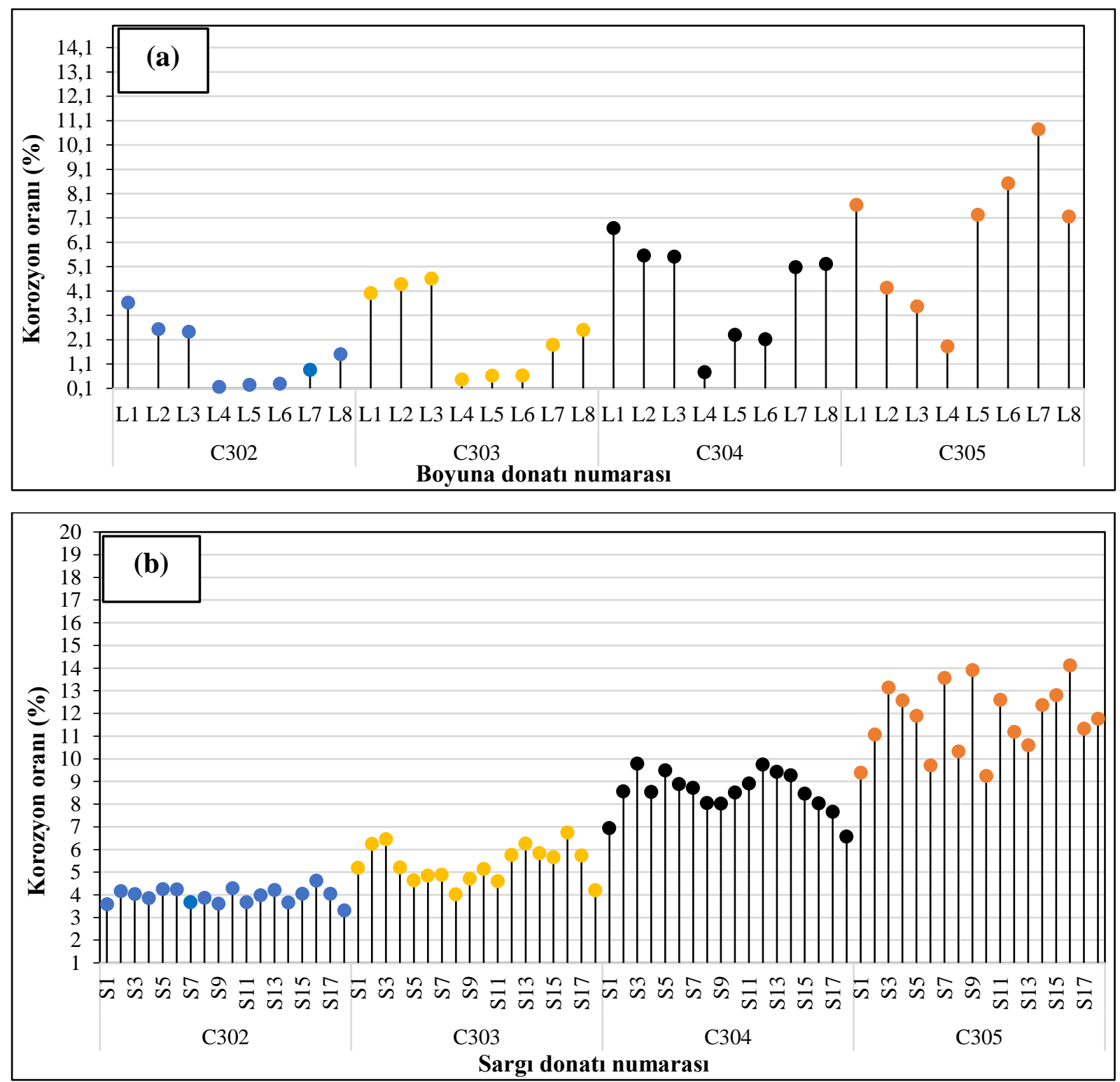

Şekil 6. Korozyon oranları: (a) boyuna donatılar; (b) sarg1 donatıları.

Tablo 1. Gravimetrik deney sonuçları.

\begin{tabular}{|c|c|c|c|c|c|c|c|c|c|c|c|c|}
\hline \multirow{2}{*}{$\begin{array}{c}\begin{array}{c}\text { Numune } \\
\text { No }\end{array} \\
\text { C30 }\end{array}$} & \multicolumn{2}{|c|}{ İlk kütle (g) } & \multicolumn{2}{|c|}{$\begin{array}{l}\text { Gerçek kütle } \\
\text { kaybı (g) }\end{array}$} & \multicolumn{2}{|c|}{$\begin{array}{c}\text { Gerçek } \\
\text { korozyon } \\
\text { oranı (\%) }\end{array}$} & \multirow{2}{*}{$\begin{array}{c}\begin{array}{c}\text { Faraday } \\
\text { kütle } \\
\text { kaybı } \\
(\%)\end{array} \\
S+L\end{array}$} & \multicolumn{2}{|c|}{$\Delta A_{s}\left(\mathrm{~mm}^{2}\right)$} & \multirow{2}{*}{$\begin{array}{c}\begin{array}{c}\text { Çekme } \\
\text { bölgesi } \\
\text { korozyon } \\
\text { oranı }\end{array} \\
\begin{array}{c}C_{L t} \\
(\%)\end{array}\end{array}$} & \multirow{2}{*}{$\begin{array}{c}\begin{array}{c}\text { Basınç } \\
\text { bölgesi } \\
\text { korozyon } \\
\text { oranı }\end{array} \\
\begin{array}{c}C_{L c} \\
(\%)\end{array}\end{array}$} & \multirow[t]{2}{*}{$\begin{array}{c}\text { Uygulanan } \\
\text { akım-saat } \\
\text { (A.h) }\end{array}$} \\
\hline & $S$ & $L$ & $S$ & $L$ & $\begin{array}{l}C_{L S} \\
(\%)\end{array}$ & $\begin{array}{l}C_{L L} \\
(\%)\end{array}$ & & $\Delta A_{s} S$ & $\Delta A_{s L}$ & & & \\
\hline $\mathrm{C} 3 \mathrm{O}_{1}$ & - & - & - & - & 0.00 & 0.00 & 0.00 & 0.00 & 0.00 & 0.00 & 0.00 & 0.00 \\
\hline $\mathrm{C} 3 \mathrm{O}_{2}$ & 8124.5 & 32488.5 & 321.0 & 474.5 & 3.95 & 1.46 & 6.50 & 1.99 & 23.49 & 2.00 & 0.95 & 2533.1 \\
\hline $\mathrm{C} 3 \mathrm{O}_{3}$ & 8099.5 & 32267.5 & 432.5 & 768.5 & 5.34 & 2.38 & 8.01 & 2.68 & 38.31 & 2.80 & 1.90 & 3104.6 \\
\hline $\mathrm{C} 3 \mathrm{O}_{4}$ & 8012.5 & 32471.5 & 683.0 & 1350.0 & 8.52 & 4.16 & 12.00 & 4.28 & 66.87 & 5.65 & 2.86 & 4663.9 \\
\hline $\mathrm{C} 3 \mathrm{O}_{5}$ & 8044.5 & 32429.5 & 945.5 & 2064.0 & 11.75 & 6.36 & 17.00 & 5.91 & 102.37 & 8.52 & 4.18 & 6604.4 \\
\hline
\end{tabular}


Tablo 1'de gösterildiği gibi beton içerisine gömülü betonarme donatılarına uygulanan hızlandırılmış korozyon yönteminin kullanıldığı deneysel çalışmalar için elde edilen gerçek korozyon oranları betonun göstermiş olduğu direnç nedeni ile teorik korozyon oranından her zaman azdir. Yalciner (2017) ve Bicer vd. (2018) tarafindan gerçekleştirilen deneysel çalışmalarda korozyon sürecinin ancak Faraday Kanununa göre korozyon oranının \%5 değerine ulaşması ile paslanmanın başladığı tespit edilmiş ve bu durum mevcut çalışma ile ayrıca desteklenmiştir. $\mathrm{Bu}$ nedenle ileriki ve büyük ölçekli betonarme elemanlarının paslandırılmasına ilişkin yapılacak deneysel çalışmalar için hedeflenen korozyon oranlarının daha iyi bir şekilde tahmin edilebilmesi için Faraday Kanununa göre hesaplanan korozyon oranlarının belirtilen seviyelerde göz önüne alınmasında faydalı olunacaktır. Tablo 1'de sarg1 donatılarının ilk kütlelerinin boyuna donatılara oranla daha az olması sebebiyle, uygulanan aynı korozyon süresi ve akım için elde edilen korozyon oranları etriyeler için daha fazladır. Bu noktada, sarg1 donatıları ile boyuna donatılarda meydana gelen korozyon oranlarının birbirlerine oranlarının göz önüne alınmasında ileriki çalışmalar için faydalı olacağı kanaati taşınmaktadır. Bilindiği üzere, betonarme elemanlarda plastik şekil değiştirmelerin ölçütü donatı sargılama etkisine bağlı olarak değişmektedir. Paslanmış betonarme elemanlarının deprem indekslerinden özellikle süneklik oranlarının tahmin edilebilmesi için göz önüne alınan korozyon oranı etkili bir rol oynamaktadır. Etriyelerde meydana gelen düşük korozyon oranına karşılık, boyuna donatılardaki yüksek korozyon oranı veya tam tersi durumu yapısal davranışı etkileyecektir. Bundan dolayı sarg1 donatıları ile boyuna donatilarda meydana gelen korozyon oranlarının birbirlerine oranlarının göz önüne alınması önerilmektedir. Tablo 1'de sarg1 donatılarından elde edilen korozyon oranlarının boyuna donatılardan elde edilen korozyon oranlarına oranı tüm betonarme kolonları için oldukça yakın olup ortalama 2'dir. Paslanmış betonarme kolonları üzerine yapılan çalışmalarda ve geliştirilen modellerde (Ma et al., 2012; Yang et al., 2016) bu durumun ihmal edilmesi sonucunda geliştirilen modeller arasında özellikle paslanmış betonarme kolanlarının sünekliği üzerine farklı sonuçlar ortaya çıkmaktadır. Paslanmış betonarme kolonlarının yapısal davranışlarını tahmin etmek için geliştirilen mevcut modeller, genellikle boyuna donatidan elde edilen ortalama korozyon oranının veya maksimum korozyon oranının kullanılması ile geliştirilen modellerdir. Ancak doğrusal olmayan yapı davranışında sarg1 donatılarının toplam yer değiştirmeye katkıları göz önüne alındığında, boyuna donatılarda aynı korozyon oranına sahip ancak etriyelerdeki farkl1 korozyon oranlarının meydana geldiği iki farklı betonarme kolonu için yapısal davranışın tamamen birbirinden farklı olacağı göz önüne alınmalıdır. Li et al. (2018) tarafından yapılan deneysel çalışmada tüm paslanmış betonarme kolonlarının sünekliği referans kolonuna göre artarken, Yang et al. (2016)'da azalım, Ma et al. (2012)'da ise \%4.1 korozyon oranına kadar tekrar artış gözlemlenmiştir. Bundan dolayı hızlandırılmış korozyon yönteminin kullanılarak paslandırıldığı betonarme elemanları için sarg1/boyuna donat1 korozyon oran katkı çarpanlarının, sarg1 donatılarının süneklik üzerindeki etkisi göz önüne alınarak dikkatlice değerlendirilmesi oldukça önemlidir.

Tablo 1 1şı̆̆ında dikkat edilmesi gereken diğer bir husus ise çekme ve basınç bölgesindeki korozyon oranlarının araştırmacılar tarafindan dikkatle değerlendirilmesidir. Mevcut çalışmanın monotonik (tek yönlü yükleme) deney 
programına sahip olmasına karşın, bu makalenin yazarları çekme ve basınç bölgesi için korozyon oranlarını ayrı olarak elde etmişlerdir. Giriş kısmında özet olarak sunulan ve mevcut literatürde geliştirilen modellerin tersinir artımlı ve yer değiştirme kontrollü yükleme programı sonucunda elde edilmesinde bu durum çok daha önem kazanmaktadır. Kolonun tek bir yüzeyinden elde edilen (itme veya çekme bölgesi) korozyon oranlarının kullanılması ile geliştirilen modeller korozyonun tersinir yük etkisi altında tüm yapı sistemini temsil edebilecek değerlerden uzaklaşmasına neden olabilir. Bu nedenle; yükleme türüne bağlı olarak geliştirilecek modellerde hangi korozyon oranlarının dikkate alınmasının iyi bir şekilde karar verilmesi ve tersinirtekrarlanır yükleme deney programları için en azından plastik mafsal bölgesi için her iki doğrultudaki korozyon oranlarının donatı kupon testleri ile tespit edilmesi gerektiği önerilmektedir.

\section{2. Çatlak desenleri}

Yükleme deneyleri sirasinda betonarme kolonlarının maksimum taşıma gücü kapasitelerinin \%85'nin aşılması ile sonlandırılan ve betonarme kolonlarında eksenel ve yanal yükün kaldırılmadan önce kayıt edilen her bir betonarme kolonu için çatlak desenleri Şekil 7'de gösterilmiştir. Monotonik yükleme ile her bir betonarme kolonu basınç bölgesindeki betonun nihai birim kısılma kapasitesinin aşılması ile göçme modları gerçekleşmiştir. Çekme çatlakları kolon boyuna donatılarına paralel yönde meydana gelirken kesme çatlakları plastik mafsal bölgesinde kolonların mesnetlenme türüne bağlı olarak temelden kolon yüksekliği boyunun yaklaşık yarısı kadar mesafede meydana gelmiştir. Korozyona maruz kalmış betonarme elemanlarının sismik performanslarının analitik yaklaşımlar ile tahmin edilebilmesine olanak sağlayan en yaygın yöntemlerden biri kesit plastik mafsal özelliklerinin korozyon etkisi ile birlikte modifiye edilmesidir. Yalciner vd. (2015) tarafindan paslanmış bir betonarme binasının zamana bağlı sismik performansının tahmin edilmesi için gerçekleştirilen çalışmada, korozyonun donatı ve beton mekanik özellikleri üzerine etkisi, aderans kuvveti ve aderans kuvvetine bağlı meydana gelen donatı sıyrılması neticesinde kesitteki ek dönme miktarı göz önüne alınarak ve kesit plastik mafsalların modifiye edilerek zaman-tanım analizinin kullanılması ile korozyona maruz kalmış bir betonarme binasının sismik performansının tahmin edildiği bir çalışmadır. Henüz mevcut literatürde korozyona maruz kalmış betonarme kolonlarının plastik mafsal boylarındaki değişkenliğini korozyonun bir fonksiyonu olarak tahmin edilebilmesine ilişkin ampirik bir model olmadığından dolayı, yapılan çalışmada plastik mafsal boyu teorik olarak hesaplanan plastik mafsal boyudur. $\mathrm{Bu}$ makalenin yazarları tarafindan yürütülen TÜBİTAK projesi ile bu konudaki eksikliğin giderilebilmesi ayrıca hedeflenmektedir. $\mathrm{Bu}$ bağlamda, Şekil 7'de gösterildiği üzere, monotonik yüklemenin plastik mafsal oluşumu üzerine zayıf etkisi ancak tersinir-tekrarlanır, artımlı ve yer değiştirme kontrollü yükleme programı ile sağlanabilir. İleriki çalışmalara 1ş1k tutması amacıyla, paslanmış betonarme kolonlarının güçlendirilmesine yönelik yapılacak olan çalışmalar için ise yalnızca plastik mafsal bölgesine odaklanmanın çok yanlış sonuçlar oluşturmayacağı önerisinde bulunulabilir. Şekil 7'de görüldüğü üzere, korozyonun çatlak oluşumu üzerine en belirgin etkilerinden biri, artan yük ile birlikte ve yaşlandırma aşamasında meydana gelen birincil korozyon çatlaklarının betonun çekme bölgesinde devam ederek genişlemesidir. Plastik mafsal bölgesinde daha belirgin bir şekilde oluşan ve kolon boyuna donatısına paralel olarak meydana gelen çekme çatlakları, korozyon oranın artması ile birlikte yükün 
uygulandığı noktaya doğru gelişme eğilimi göstermiştir. Paslandırılmış betonarme kolonlarının hasar seviyeleri daha az eğilme kapasitesi ile birlikte artan korozyon oranı ile artmıştır.
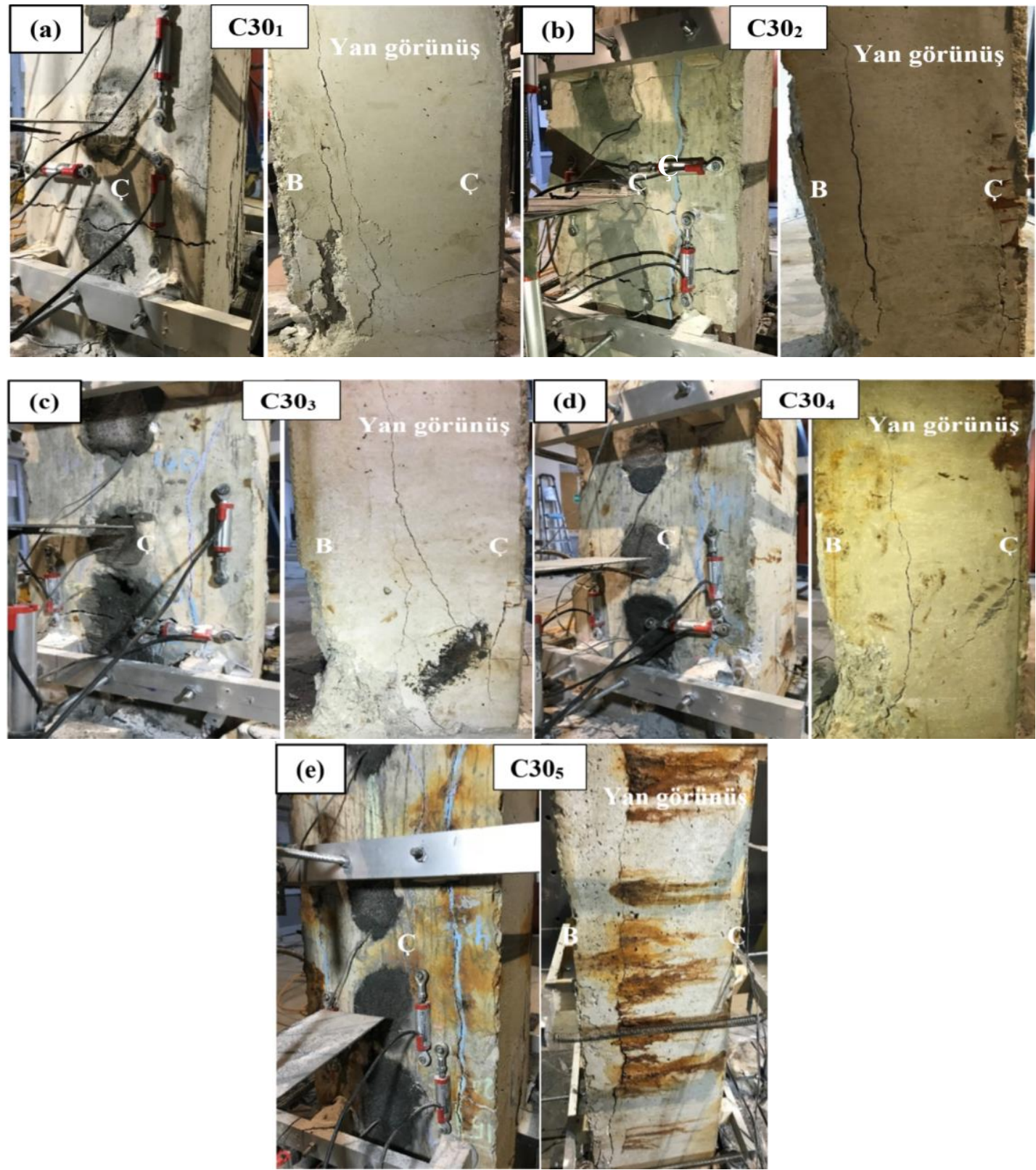

Şekil 7. Her bir betonarme kolon için oluşan çatlak desenleri: (a) $\mathrm{C} 30_{1}$ kolonu; (b) $\mathrm{C} 3 \mathrm{O}_{2}$ kolonu; (c) $\mathrm{C}_{30} 3_{3}$ kolonu; (d) $\mathrm{C} 30_{4}$ kolonu; (e) $\mathrm{C} 30_{5}$ kolonu.

Ç: Çekme bölgesi; B: Basınç bölgesi.

Her bir betonarme kolonu boyunca, maksimum uygulanan yanal yükün \%85'ine karşılık ölçülen dönme açıları ve dönme açılarına bağlı olarak hesaplanan eğrilik değerleri Şekil 8'de gösterilmektedir. Şekil 8 'de gösterildiği üzere korozyon oranının artması ile birlikte betonarme kolonlarının plastik mafsal boyları da azalmıştır. Paslanmamış betonarme kolonu olan C $30_{1}$ için hesaplanan plastik mafsal boyu 164.63 mm iken, korozyon seviyesinin artırıldı ğ $\mathrm{C} 30_{2}, \mathrm{C} 30_{3}, \mathrm{C} 3 \mathrm{O}_{4}$ ve $\mathrm{C} 30_{5}$ numuneleri için 
sirasıyla plastik mafsal boyları 139.42, 94.18, 82.95 ve $58.65 \mathrm{~mm}$ olarak hesaplanmıştır.

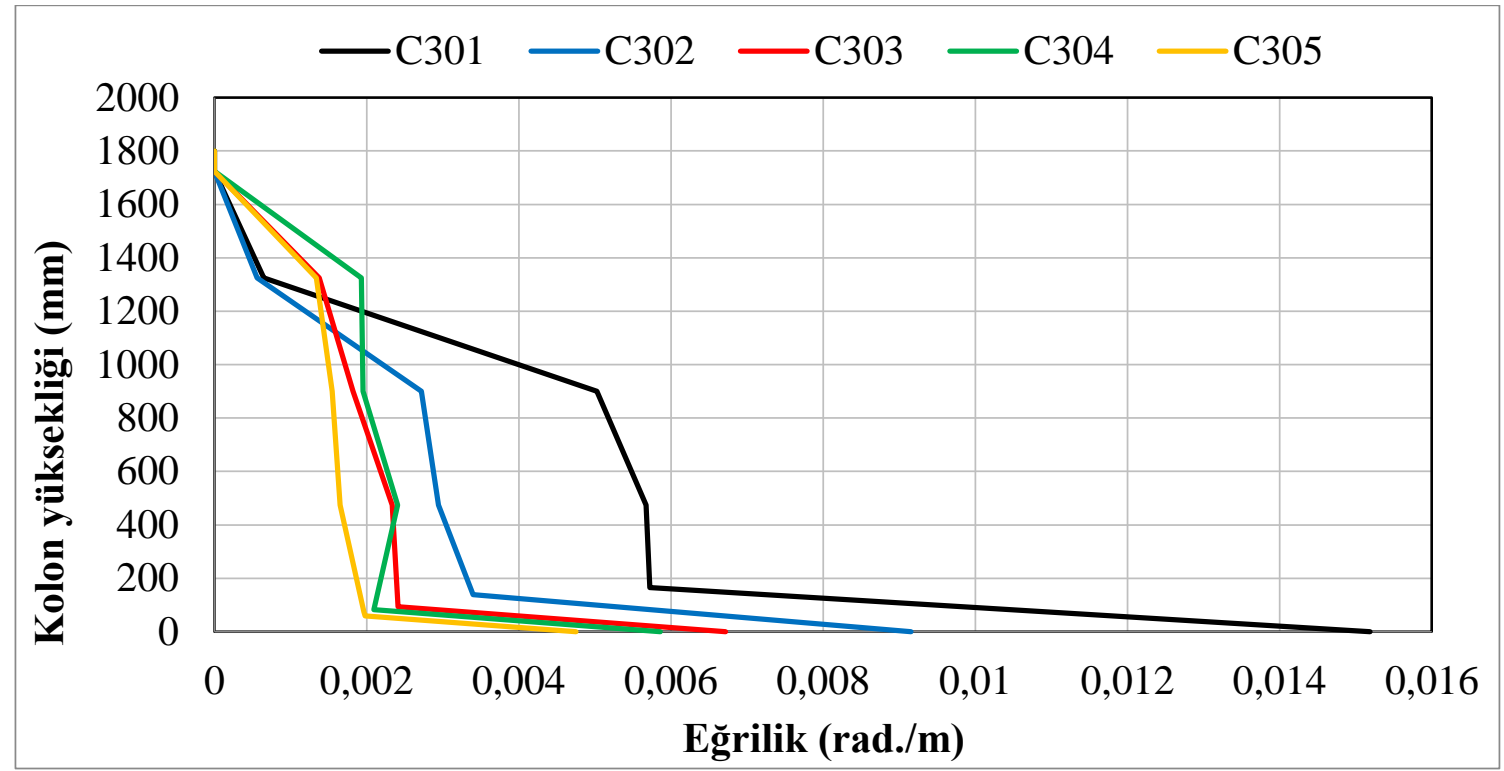

Şekil 8. Her bir betonarme kolon için hesaplanan kolon yükseklik-eğrilik ilişkisi.

\subsection{Yük-deplasman sonuçları}

Monotonik yükleme deneyleri sonucunda beş adet betonarme kolonları için elde edilen yük-deplasman ilişkileri Şekil 9'da gösterilmektedir.

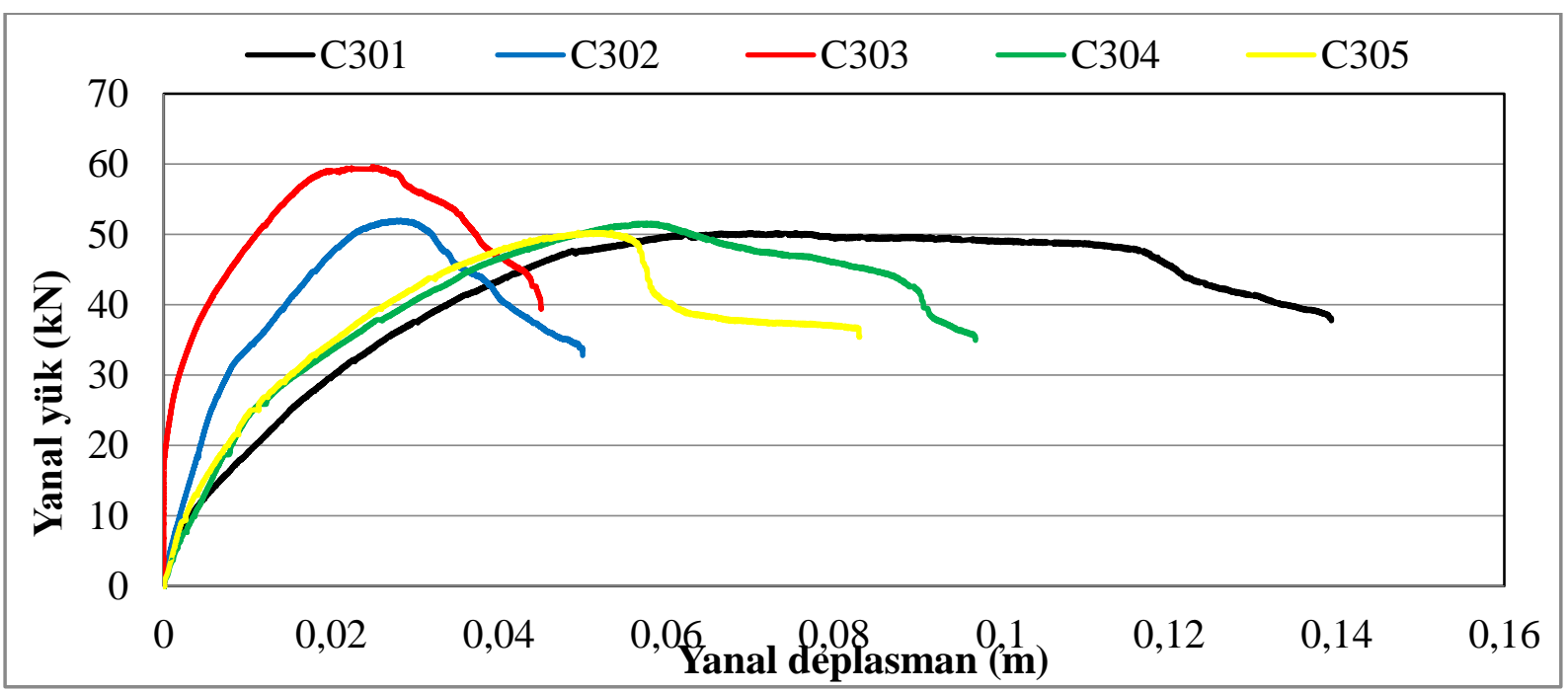

Şekil 9. Her bir betonarme kolon için oluşan yük-deplasman ilişkisi.

Betonarme kolon numunelerinin akma dayanımları ve bunlara karşılık gelen yer değiştirmeler ölçülen yük-deplasman eğrilerinin Sezen (2000) modeline göre
Şekil 10'da gösterildiği gibi idealize edilerek elde edilmiştir. Şekil 10'da yanal yük-deplasman eğrisinin orijinden maksimum yanal yükün \%70'ine karşılık 
gelen ve yanal-yük deplasman eğrisini kesen ikincil bir çizgi çizilmiştir. Bu çizgi, aynı rijitliğe sahip olarak maksimum yanal yüke karşılık gelen yatay çizgi ile kesişme noktasına uzatılmıştır. Uzatılan çizgi akma noktasını elde etmek için yatay eksen üzerine yansitılmıştır. Nihai yer değiştirmeler ise maksimum uygulanan yanal yükün \%85'ine karş1lık ölçülen maksimum yer değiştirme olarak tanımlanmıştır. $\mathrm{Bu}$ yöntem kullanılarak hesaplanan kuvvet-deplasman ve süneklik oranları Tablo 2'de özet olarak sunulmuştur.

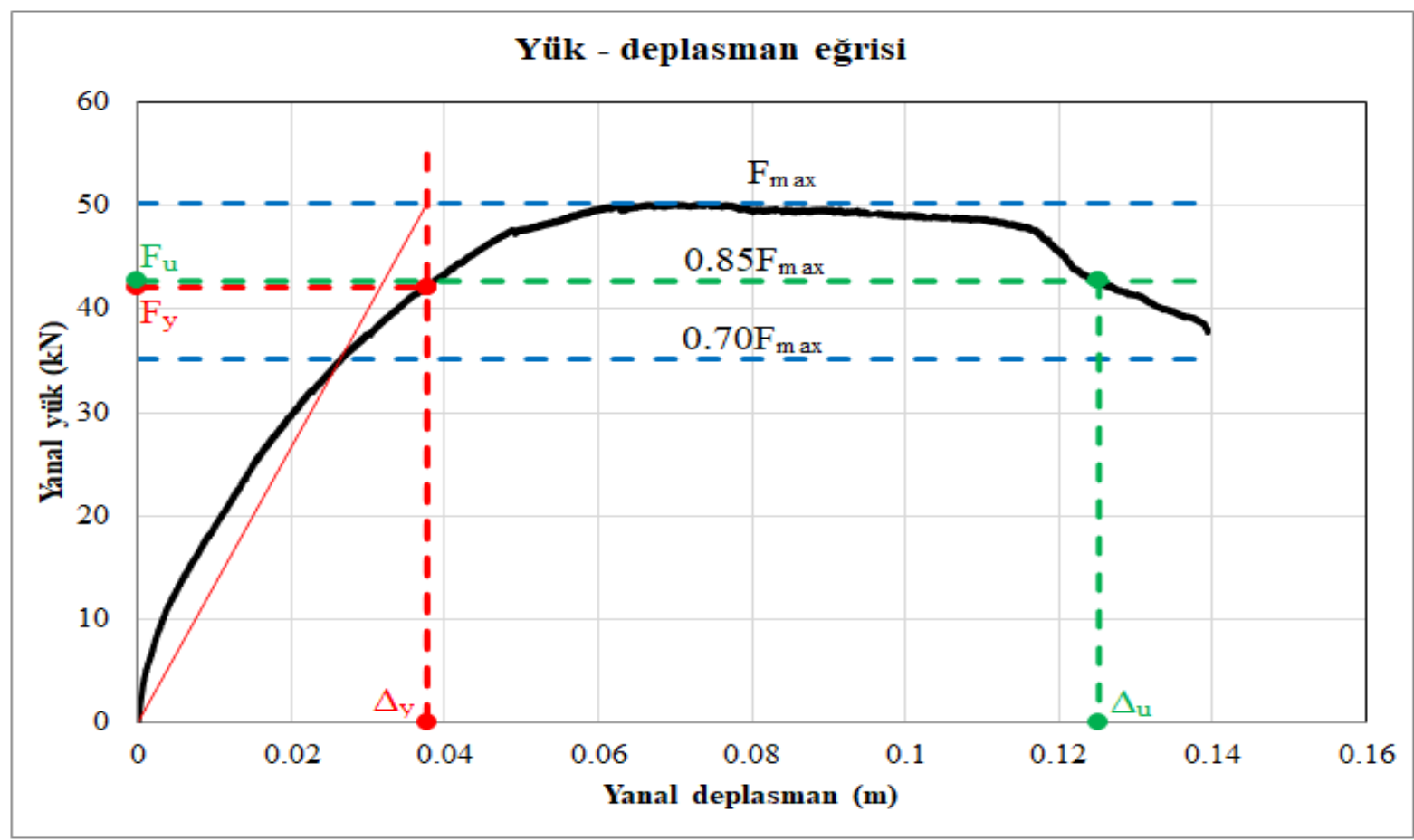

Şekil 10. Sezen (2000) idealize yönteminin şematik gösterimi.

Tablo 2: Deneysel sonuçları.

\begin{tabular}{ccccccccc}
\hline Kolon & $\begin{array}{c}\boldsymbol{F}_{\boldsymbol{y}} \\
(\mathbf{k N})\end{array}$ & $\begin{array}{c}\boldsymbol{F}_{\boldsymbol{u}} \\
(\mathbf{k N})\end{array}$ & $\begin{array}{c}\boldsymbol{\Delta}_{\boldsymbol{y}} \\
(\mathbf{m})\end{array}$ & $\begin{array}{c}\boldsymbol{\Delta}_{\boldsymbol{u}} \\
(\mathbf{m})\end{array}$ & $\boldsymbol{\mu}$ & $\begin{array}{c}\boldsymbol{E} \\
(\mathbf{j o u l e})\end{array}$ & $\begin{array}{c}\boldsymbol{C}_{\boldsymbol{L L}} \\
(\boldsymbol{\%})\end{array}$ & $\begin{array}{c}\boldsymbol{C}_{\boldsymbol{L S}} \\
(\boldsymbol{\%})\end{array}$ \\
\hline $\mathrm{C} 30_{1}$ & 42.10 & 42.71 & 0.04 & 0.13 & 3.32 & 5239.63 & 0.00 & 0.00 \\
$\mathrm{C} 30_{2}$ & 44.05 & 44.19 & 0.02 & 0.04 & 2.14 & 1465.00 & 1.46 & 3.95 \\
$\mathrm{C} 303_{3}$ & 46.14 & 59.65 & 0.01 & 0.02 & 2.88 & 1218.71 & 2.38 & 5.34 \\
$\mathrm{C}_{4} 0_{4}$ & 42.61 & 49.06 & 0.03 & 0.07 & 1.98 & 2506.77 & 4.16 & 8.52 \\
$\mathrm{C} 305_{5}$ & 42.03 & 50.31 & 0.03 & 0.05 & 1.67 & 1749.64 & 6.36 & 11.75 \\
\hline
\end{tabular}

Şekil 9'da ve deney sonuçlarının özet olarak sunulduğu Tablo 2'de görüldüğü üzere, korozyon ürününün betonarme donatısında sağladığı sargılama nedeni ile belirli bir korozyon oranına kadar akma ve nihai yük dayanımlarında artışlar gözlenmektedir. Söz konusu artışlar aderans kuvvetinin ve donat1 siyrilmasinın toplam yer değiştirmeye katkısından dolayıdır. Ancak monotonik yüklemenin gerilme dağılımın yeniden oluşmasına imkân veren tersinir yüklemeye göre daha az etkisinden dolayı artış ve azalış değerleri sınırlı seviyelerde kalmaktadır. Elde edilen deneysel veriler süneklik açısından ele alındığında ise; korozyon oranının artması ile birlikte paslanmış betonarme kolonlarının süneklikleri azalmaktadır. Belirli bir korozyon oranına kadar aderans kuvvetindeki artışa bağlı olarak korozyona 
maruz kalmış betonarme kolonlarının sünekliklerinde artış görülmesi beklenmektedir. Ancak monotonik yükleme sonucunda korozyonun bu etkisi tam olarak görülememektedir. Bunun nedeni, çekme bölgesinde meydana gelen birincil korozyon çatlakların artan yük etkisi ile birlikte genişleyerek devam etmesidir. Monotonik yükleme deneyleri sonucunda korozyon oranına bağlı olarak azalan süneklikler ve $\mathrm{C}_{3} \mathrm{O}_{3}$ betonarme kolonu için elde edilen artış, eşdeğer enerji yöntemi kapsamında farklı rijitliklerden dolayı elde edilen değerlerdir. Elde edilen deneysel veriler kullanılarak, monotonik yükleme sonucunda paslanmış betonarme kolonlarının süneklik oranlarının tahmin edilebilmesi için geliştirilen ampirik model Denklem 3'de sunulmuştur.

$$
\frac{\mu_{c}}{\mu_{o}}=\frac{1}{\left(1+0.34 C L_{L}-0.03 C L_{L}^{2}\right)}
$$

Denklem 3'de $\mu_{c}$ ve $\mu_{o}$ sirasiyla korozyonlu ve korozyonsuz betonarme kolonların süneklik oranlarını ve $C_{L L}$ boyuna donatı korozyon oranını ifade etmektedir.

Tablo 2'de gösterildiği üzere, korozyona maruz kalmış betonarme kolonları enerji yutma kapasiteleri açisından değerlendirildiğinde, korozyonun yapısal davranış üzerine etkisi açık bir şekilde görülmektedir. Aynı eksenel yük etkisi altında paslandirılmayan $\mathrm{C} 30_{1}$ betonarme kolonun enerji yutma kapasitesi $\mathrm{C}_{3} \mathrm{O}_{5}$ betonarme kolonu ile karşılaştırıldığında, \%67 oranında azalmaktadır. Belirli seviyelerdeki korozyon oranlarına kadar, toplam enerji yutma kapasitesinin arttığ ve ileri korozyon oranları için azaldığı göz önüne alındığında, bu çalışmanın yazarları tarafindan, korozyonun yapısal davranış üzerine etkisinin ortaya konulabilmesi için tersinir yükleme programından elde edilecek hasar indekslerinin tanımlanmasının faydalı olacağı önerilmektedir. Monotonik yükleme etkisi altında deneyleri gerçekleştirilen betonarme kolonlarından elde edilen deneysel sonuçlar ışığında, paslanmış betonarme kolonlarının enerji yutma kapasitelerinin tahmin edilebilmesi için geliştirilen ampirik model Denklem 4'de sunulduğu gibidir.

$$
\frac{E_{c}}{E_{o}}=\frac{1}{\left(1+1.87 C L_{L}-0.19 C L_{L}^{2}\right)}
$$

\section{Sonuç}

Tam ölçekli paslandırma havuzu kullanılarak paslandırılan betonarme kolon numuneleri davranışlarına ilişkin yapılan deneysel çalışma kapsamında aşağıda sunulan sonuçlar ve önerilere ulaşılmıştır.

- Servis yükleri veya servis yükleri olmadan paslandirılan betonarme elemanları için, yükleme türünün korozyon oranına bağlı olarak donatı çapındaki azalmay1 etkilemeyeceği göz önüne alınarak, servis yükleri olmadan paslandırılacak betonarme elemanlarından elde edilen deneysel veriler, servis yükleri kullanılarak elde edilen deneysel veriler ile ilişkilendirilebileceği önerilebilir.

- Büyük ölçekli betonarme elemanlarının paslandırılmasına ilişkin yapılacak deneysel çalışmalarda korozyon sürecinin başlayabilmesi için Faraday Kanununa göre hesaplanan teorik korozyon oranının en düşük seviyesi için $\% 5$ olarak alınması gerektiği savunulmaktadır.

- Kesme kuvvetinin yanal ötelenmeye katkısının göz önüne alınması veya ihmalini gerektiren durumlar için boyuna ve etriyelerde meydana gelen korozyon oranlarının dikkatlice tespit edilmesi gerekmektedir. Yalnızca boyuna donatılarda meydana gelen korozyon oranlarının dikkate alınması ile geliştirilecek yapısal modeller için, boyuna donatılardaki ortalama korozyon oranı ve etriyelerdeki ortalama korozyon oranlarının 
deney numuneleri arasında ilişkilendirilmesi gerekmektedir.

- Yükleme türüne bağlı olarak çekme ve basınç bölgeleri için ayrı ayrı belirlenebilecek korozyon oranlarının, geliştirilecek modellerde dikkate alınmasının önemli olduğu vurgulanmaktadir.

- Monotonik yükleme etkisi altında ve artan birincil korozyon çatlakları ile birlikte betonarme kolonlarının yer-değiştirme bazlı süneklik oranları ve enerji yutma kapasiteleri korozyon oranına bağlı olarak azalmıştır. Mevcut literatürde paslanmış betonarme kolonlarının tersinir yükleme etkisi altında süneklik oranlarının artmasına ilişkin çelişkili sonuçlar için enerji indekslerine bağlı olarak hesaplanacak süneklik oranları önerilmektedir.

- Korozyonun deprem indeksleri açısından artan ve azalan eğilimleri göz önüne alındığında, hasar indeksine dayalı bir değerlendirmenin daha sağlıklı sonuçlar vereceği düşünülmektedir.

- Ülkemizde hali hazırda korozyona maruz kalmış betonarme yapıların kapsamlı değerlendirilmesine olanak sağlayacak yöntem ve modeller yönetmeliklerde yer almamakla beraber, korozyonun etkisi yalnızca donatı çapındaki azalma olarak göz önüne alınmaktadır. Betonarme kolonları için devam eden çelişkili durumlara karşılık, başarılı olarak sonuçlandırılan kiriş modellerin mühendislerin kullanımına sunulması amacı ile deprem yönetmeliğine söz konusu çalışmaların ilave edilmesi bu çalışmanın yazarları tarafindan önemle belirtilmektedir.

\section{Teşekkür}

$\mathrm{Bu}$ çalışmanın finansal desteği Türkiye Bilimsel ve Teknolojik Araştırma Kurumu TÜBITAK 3501 ve $116 \mathrm{M} 162$ numaralı proje kapsamında desteklenmiştir. Araştırmanın yazarları TÜBİTAK kurumuna desteklerinden dolayı teşekkürü bir borç bilir.

\section{Kaynaklar}

ASTM (American Standards for Testing and Materials), (2003). "Standard practice for preparing, cleaning, and evaluating corrosion test specimens" G1-03, West Conshohocken, PA, 1-9.

ASTM (American Standards for Testing and Materials), (2008). "Standard test methods and definitions for mechanical testing of steel products" A370, West Conshohocken, PA, 1-47.

Ahmad, S. (2017). "Prediction of residual flexural strength of corroded reinforced concrete beams" Anti-Corros. Methods Mater., 64(1), 69-74.

Amleh, L., Ghosh, A. (2006). "Modeling the effect of corrosion on bond strength at the steel-concrete interface with finiteelement analysis" Can. J. Civ. Eng., 33(6), 673-682.

Auyeung, Y., Balaguru, P., Chung, L. (2000). "Bond behavior of corroded reinforcement bars" Mater. J., 97(2), 214220.

Azad, AK., Ahmad, S., Al-Gohi, BHA. (2010). "Flexural strength of corroded reinforced concrete beams" Mag. Concr. Res., 62(6), 405-414.

Bicer, K., Yalciner, H., Pekrioglu, BA., Kumbasaroglu, A. (2018). "Effect of corrosion on flexural strength of reinforced concrete beams with polypropylene fibers" Constr. Build. Mater., 185, 574-588.

Campione, G., Cannella, F., Cavaleri, L. (2017). "Shear and flexural strength prediction of corroded RC beams" Constr. Build. Mater., 149, 395-405.

Chung, L., Cho, SH., Kim, JHJ., Yi, ST. (2004). "Correction factor suggestion for 
ACI development length provisions based on flexural testing of RC slabs with various levels of corroded reinforcing bars" Eng. Struct., 26(8), 1013-1026.

Coronelli, D., Gambarova, P. (2004). "Structural assessment of corroded reinforced concrete beams: modeling guidelines" J. Struct. Eng., 130(8), 12141224.

FEMA (Federal Emergency Management Agency), (2007). "Interim testing protocols for determining the seismic performance characteristics of structural and nonstructural components" FEMA-461, Washington, DC, 1-113.

El Maaddawy, T., Soudki, K., Topper, T. (2005). "Long-term performance of corrosion-damaged reinforced concrete beams" ACI Struct. J., 102(5), 649-56.

El Maaddawy, T., Chahrour, A., Soudki, K. (2006). "Effect of fiber-reinforced polymer wraps on corrosion activity and concrete cracking in chloride-contaminated concrete cylinders" J. Compos. Constr., 10(2), 139147.

Guo, A., Li, H., Ba, X., Guan, X., Li, H. (2015). "Experimental investigation on the cyclic performance of reinforced concrete piers with chloride-induced corrosion in marine environment" Eng. Struct., 105, 111.

Hanjari, KZ., Kettil, P., Lundgren, K. (2011). "Analysis of mechanical behavior of corroded reinforced concrete structures" ACI Struct. J., 108(5), 532-541.

Jnaid, F., Aboutaha, RS. (2016). "Residual flexural strength of corroded reinforced concrete beams" Eng. Struct., 119, 198-216.

Kalyoncuoglu, A., Ghaffari, P., Goksu, C., Ilki, A. (2013). "Rehabilitation of corrosion-damaged substandard RC columns using FRP sheets" Adv. Mater. Res., 639-640, 1096-1103.

Lee, HS., Kage, T., Noguchi, T., Tomosawa, F. (1999). "The evaluation of flexural strength of RC beams damaged by rebar corrosion" Proceeding of 8th International Conference, Durability of Building Materials and Components, Ottawa, Canada, 321-330.

Li, D., Wei, R., Xing, F., Sui, L., Zhou, Y., Wang, W. (2018). "Influence of Nonuniform corrosion of steel bars on the seismic behavior of reinforced concrete columns" Constr. Build. Mater., 167, 2032.

Liu, Y., Weyers, RE. (1998). "Modeling the time-to-corrosion cracking in chloride contaminated reinforced concrete structures" ACI Mater. J., 95(6), 675-680.

Ma, Y., Che, Y., Gong, J. (2012). "Behavior of corrosion damaged circular reinforced concrete columns under cyclic loading" Constr. Build. Mater., 29, 548-556.

Malumbela, G., Alexander, M., Moyo, P. (2009). "Steel corrosion on RC structures under sustained service loads-A critical review” Eng. Struct., 31(11), 2518-2525.

Meda, A., Mostosi, S., Rinaldi, Z., Riva, P. (2014). "Experimental evaluation of the corrosion influence on the cyclic behaviour of RC columns" Eng. Struct., 76:112-23.

O'Flaherty, FJ., Mangart, PS., Lambert, P., Browne, EH. (2008). "Effect of under reinforcement on the flexural behaviour of corroded beams" Mater. Struct., 41(2), 311321.

Paul, SC., Babafemi, AJ., Conradie, K., van, Zijl, GPAG. (2016). "Applied voltage on corrosion mass loss and cracking behavior of steel-reinforced SHCC and mortar specimens" J. Mater. Civil. Eng., 29(5), 1-9. 
Sezen, H. (2000). "Seismic behavior and modeling of reinforced concrete building columns" Doctor of Philosophy, Engineering - Civil and Environmental Engineering, University of California, Berkeley, 1-336.

Yalciner, H., Eren, O., Sensoy, S. (2012). "An experimental study on the bond strength between reinforcement bars and concrete as a function of concrete cover, strength and corrosion level" Cem. Concr. Res., 42(5), 643-655.

Yalciner, H., Sensoy, S., Eren, O. (2015). "Seismic performance assessment of a corroded 50-year-old reinforced concrete building” J. Struct. Eng., 141(12), 1-11.

Yalciner, H. (2017). "Paslanmaya maruz kalmış betonarme kirişlerde geo-grid kullanımının süneklik üzerindeki etkisi" FBA-2016-330, Erzincan Üniversitesi Bilimsel Araştırma Projeleri Koordinasyon Birimi, 13 pp.

Yang, SY., Song, XB., Jia, HX., Chen, X., Liu, XL. (2016). "Experimental research on hysteretic behaviors of corroded reinforced concrete columns with different maximum amounts of corrosion of rebar" Constr. Build. Mater., 121, 319-327. 